\title{
Mast cells in the labial salivary glands of patients with Sjögren's syndrome: a histochemical, immunohistochemical, and electron microscopical study
}

Yrjö T Konttinen, Susanne Tuominen, Margaretha Segerberg-Konttinen, Peter Jungell, Maria J Malmström, Mats Grönblad, Orhan Guven, Seppo Santavirta, Pertti Panula

\begin{abstract}
Mast cells in labial salivary glands obtained from patients with xerostomia with or without focal sialadenitis/Sjögren's syndrome were studied. There was no significant correlation between the intensity of local lymphocyte infiltration and the morphometrically analysed number of mast cells staining positive with toluidine blue. Histamine staining with heterologous 11C antiserum showed significantly fewer positive cells than staining with toluidine blue (mean (SD) 62 (10) $v 138(30)$ ). This suggests heterogeneity of the mast cell population. Furthermore, there was a correlation between the focus score and the number of mast cells containing histamine. This suggests that the proliferation of mast cells containing histamine may be locally regulated by the immune inflammation, possibly through mediators from macrophages and fibroblasts. In contrast, the number of mast cells staining positive with toluidine blue could not be used as a marker of the degree of local inflammation. Although transmission electron microscopic analysis did not disclose signs of 'en masse' mast cell degranulation, mast cells may have a role in the local disease process.
\end{abstract}

Previously, mast cells have been mainly associated with hypersensitivity reactions. Mast cell mediators, however, play a part not only in hypersensitivity reactions but also in the inflammation process. ${ }^{12}$ Several recent studies focusing on mast cells in inflammatory diseases have detected increased numbers of cells in various connective tissue diseases, including synovial tissue in rheumatoid arthritis (RA). ${ }^{34}$ In Sjögren's syndrome the salivary glands gradually become filled with inflammatory cells. The focal sialadenitis may be responsible for the xerostomia of patients with Siögren's syndrome. ${ }^{56}$ Mast cells were previously studied by metachromatic toluidine blue staining of the labial salivary glands of patients fulfilling the 1958 criteria of the American Rheumatism Association for RA. ${ }^{7}$ The study showed that the number of mast cells was higher in patients than in healthy controls. ${ }^{7}$ This finding may indicate that many patients with chronic RA have some type of underlying, secondary Sjögren's syndrome. As the inflammatory component of the salivary glands of patients with Sjögren's syndrome is obvious, 8 and as previous studies indicate that mast cells may participate in sialadenitis, we decided to study the number and degree of degranulation of mast cells in labial salivary gland biopsy specimens of patients with Sjögren's syndrome. The aim was to evaluate the eventual participation of mast cells in this particular inflammatory process.

\section{Patients and methods}

PATIENTS

Labial salivary gland biopsy specimens were obtained from 12 patients, who had all given their informed consent to the biopsy. The project was also accepted by the local ethical committee. Eight patients had Sjögren's syndrome according to the Copenhagen criteria two had primary Sjögren's syndrome and six secondary Sjögren's syndrome associated with RA according to the 1987 criteria of the American Rheumatism Association. ${ }^{10}$ The remaining four patients had other diseases-two patients had RA, one systemic lupus erythematosus, and one sialolithiasis. The patients who did not, in the final evaluation, have Sjögren's syndrome, were suspected of having that condition on clinical grounds. Labial salivary gland biopsy may be the single most important procedure in confirming or excluding Sjögren's syndrome which has been indicated clinically $^{8}$ and is therefore suggested to all patients with possible Sjögren's syndrome at our institution. All patients had foci in their labial salivary gland biopsy specimens, but the focus score exceeded one only in patients with Sjögren's syndrome.

\section{BIOPSY SPECIMENS}

Labial salivary gland biopsy specimens were taken under local anaesthesia (Citanest-Octapressin, Asta, Södertälje, Sweden). A long transverse incision (about $20 \mathrm{~mm}$ ) was made on the mucosa of the lower lip, close to the comissure, to avoid disturbing the sensory nerves. The salivary glands were removed separately by blunt dissection, and frozen. ${ }^{8}$

DEMONSTRATION OF MAST CELLS WITH TOLUIDINE BLUE STAINING

For staining with toluidine blue the frozen glands were cut in a cryostat. The specimens ( 6 $\mu \mathrm{m}$ thick) were fixed in cold $\left(4^{\circ} \mathrm{C}\right)$ acetone for five minutes. After fixation the specimens were washed in phosphate buffered saline (PBS), $\mathrm{pH}$ $7 \cdot 2$, and then stained with toluidine blue for five minutes. After staining, the specimens were washed in running water for 10 minutes, 
dehydrated in alcohol, cleared, and then mounted.

\section{IMMUNOHISTOCHEMICAL STAINING FOR MAST \\ CELLS}

The frozen specimens ( $6 \mu \mathrm{m}$ thick) were fixed in paraformaldehyde for five minutes and then washed in PBS. Intrinsic peroxidase was inhibited by pretreating the specimens with $3 \% \mathrm{H}_{2} \mathrm{O}_{2}$ diluted with PBS for five minutes. After washing the specimens in phosphate buffered saline they were treated sequentially with peroxidaseantiperoxidase staining ${ }^{11}$ : (1) normal swine serum (dilution 1:5; Dakopatts, Copenhagen, Denmark) for 30 minutes; (2) 11C antiserum specific for histamine (dilution 1:500) for 60 minutes ${ }^{12}{ }^{13}$; (3) swine-antirabbit IgG (dilution 1:200, Dakopatts) for 30 minutes; (4) horseradish peroxidase-antihorseradish peroxidase complex (dilution 1:200; Dakopatts) for 30 minutes.

After stages 2, 3, and 4 the specimens were washed in PBS. 3,3-Diaminobenzidine tetrahydrochloride was used to produce the peroxidase colour reaction. The tissue sections were incubated in 3,3-diaminobenzidine tetrahydrochloride (50 mg in $150 \mathrm{ml}$ PBS) with $0.003 \%$ $\mathrm{H}_{2} \mathrm{O}_{2}$ substrate for seven minutes and then washed in PBS. Counterstaining was performed with haematoxylin. The specimers were finally washed, dehydrated, cleared, and mounted. To test the specificity of the immunoperoxidase staining the first antiserum was replaced by either PBS or normal rabbit serum.

\section{TRANSMISSION ELECTRON MICROSCOPY}

Several small (about $1 \mathrm{~mm}^{3}$ ) pieces were cut for ultrastructural study from three patients with Sjögren's syndrome. This tissue was fixed for one hour in $3 \%$ phosphate buffered glutaraldehyde and post-fixed in osmium tetraoxide. After dehydration in ethanol the specimens were embedded in Epon and sectioned into 40-60 nm thick sections. The specimens were mounted in copper grids coated with Formvar and stained in uranyl acetate. The mast cells were examined with a JEOL LEM-1200 EX transmission electron microscope.

\section{EVALUATION OF THE RESULTS}

The number of mast cells in the specimens stained with toluidine blue and histamine specific $11 \mathrm{C}$ was counted by oil immersion, in a light microscope (magnification $\times 1000$ ). The interobserver coefficient of variation was less than 0.05 for toluidine blue and histamine staining.

The intensity of inflammation was determined by counting the inflammatory cell foci/ 4 $\mathrm{mm}^{2}$ of glandular tissue, thus determining the focus score index as described by Greenspan et $a l .{ }^{14}$ The mean (SD) was used to express dispersion. The significance of the differences was tested with Wilcoxon's rank sum test. Linear regression analysis was used to study the correlation between two variables.

\section{Results}

After staining with toluidine blue the metachromatic mast cells were seen as violet, granular mononuclear cells (fig 1). Histamine staining using $11 \mathrm{C}$ antiserum in the peroxidase-antiperoxidase method stained mast cells brown (fig 2). Mast cells were usually located in the periphery of the lymphocyte foci or diffusely

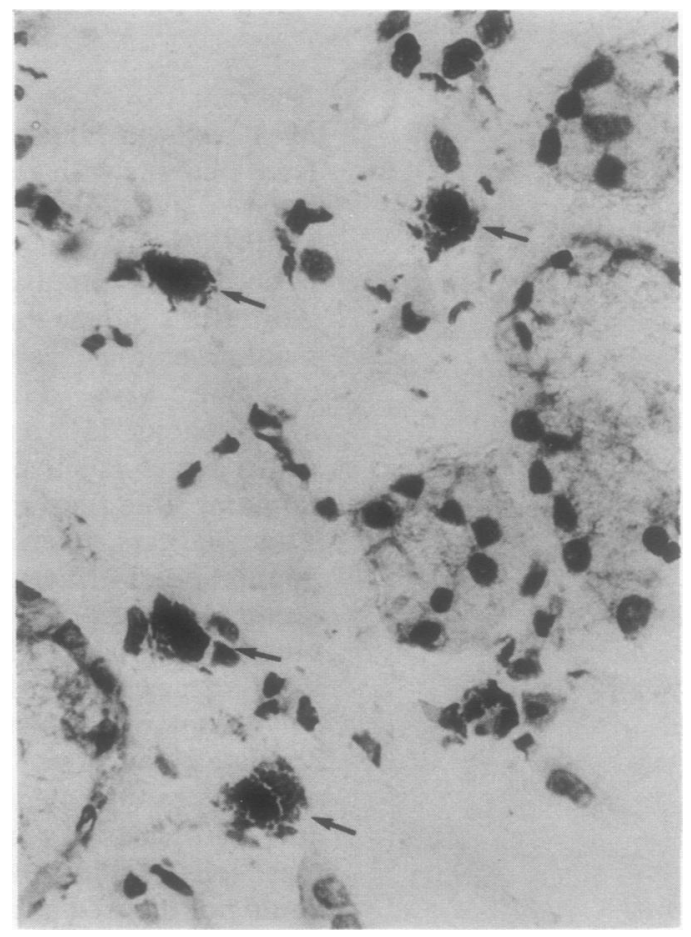

Figure 1 Mast cells in a labial salivary gland of a patient with Sjögren's syndrome stained with toluidine blue. The mast cells are here seen as round or ovoid granular cells (arrows).

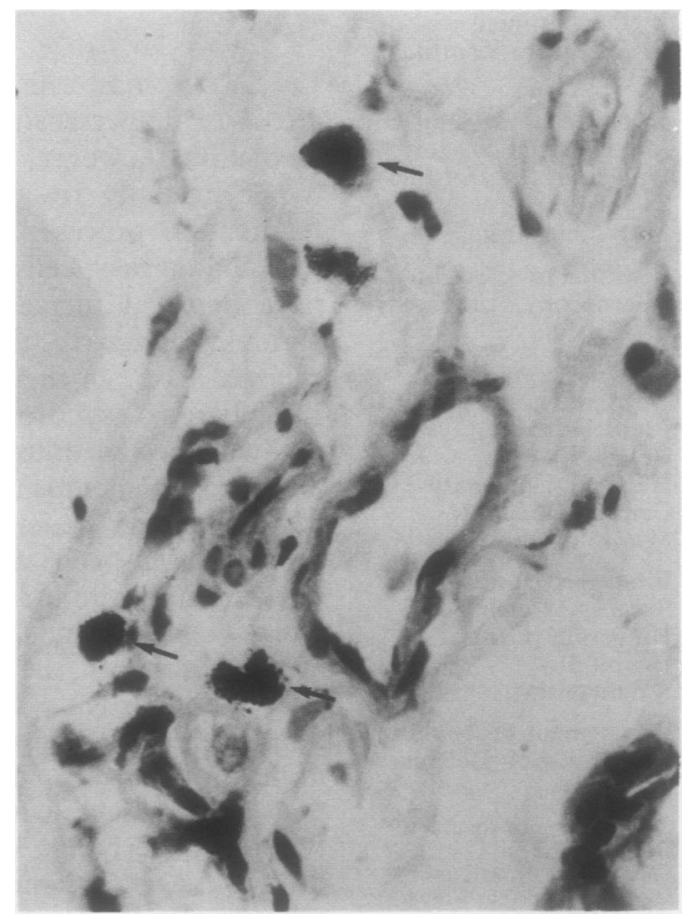

Figure 2 Mast cells in a labial salivary gland of a patient with Sjögren's syndrome stained with histamine specific 11C antiserum. The histamine positive brown cells are here marked with arrows. 
scattered in the salivary tissue stroma. Staining controls confirmed the specificity of immunoperoxidase staining. Plain transmission electron microscopy showed typical nuclear morphology and cytoplasmic granules (fig 3).

Morphometry disclosed 138 (30) mast cells per $10 \mathrm{~mm}^{2}$ labial salivary gland tissue stained positive with toluidine blue, but there was no correlation between the number of mast cells and the intensity of inflammation as assessed by focus score counting $(y=1 \cdot 323+0.007 x$, $r=0.486, p>0.05$; fig 4).

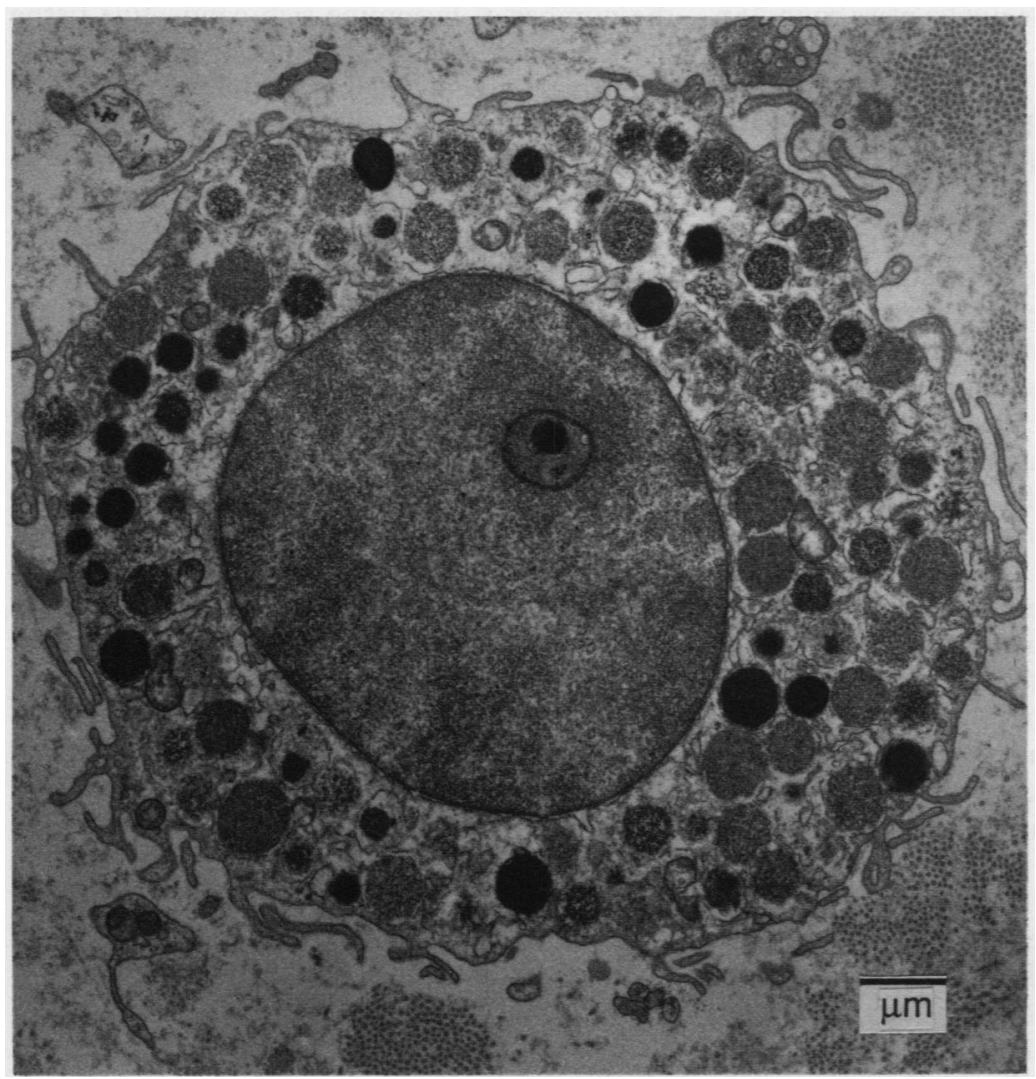

Figure 3 Ultrastructural appearance of a mast cell in a labial salivary gland of a patient with Sjögren's syndrome. Note the abundance of secretory granules lacking signs of degranulation.

Figure 4 Dependence of toluidine blue positive metachromatic mast cell number on the intensity of the local tissue inflammation as assessed by focus score.

$y=1 \cdot 323+0.007 x$,

$r=0.486, p>0.05$ in linear regression analysis. LSG=labial salivary gland.

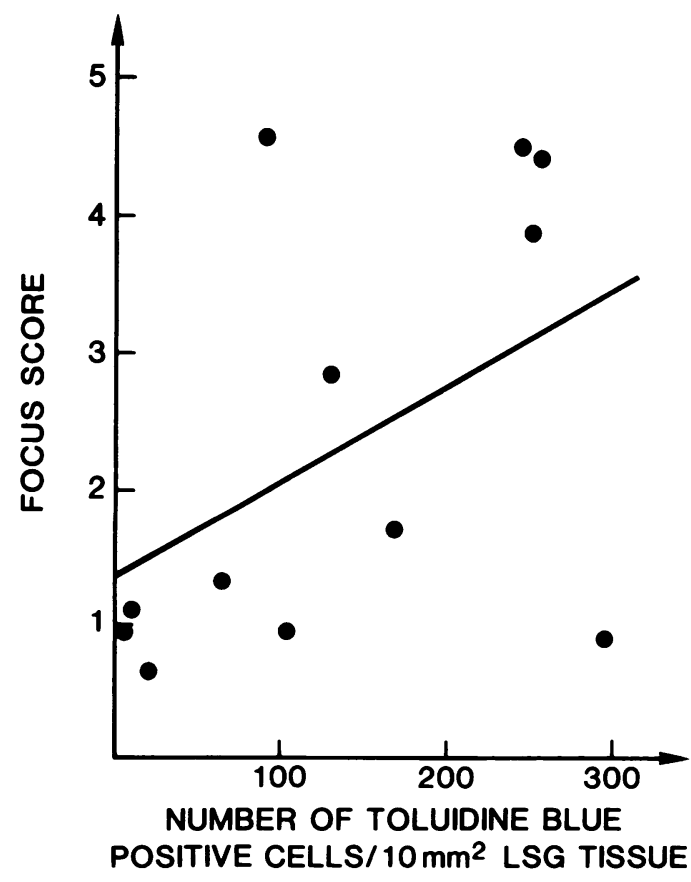

In contrast with staining with toluidine blue, 11C staining disclosed only 62 (10) mast cells per $10 \mathrm{~mm}^{2}$ labial salivary gland tissue. This difference was significant as compared with the number of cells stained positive with toluidine blue ( $p=0.01$; fig. 5 ). Furthermore, there was a significant correlation between the degree of

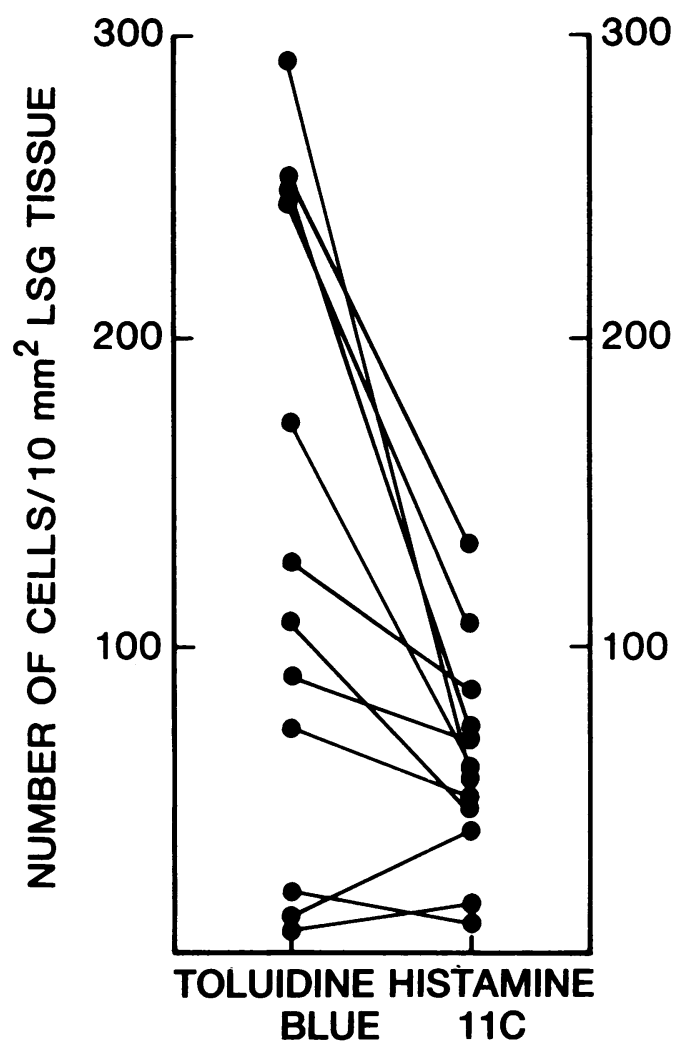

Figure 5 Comparison between the morphometrically evaluated number of toluidine blue positive cells and the mumber of histamine positive cells. Wilcoxon's rank sum test for paired samples, $p=0 \cdot 01 . L S G=$ labial salivary gland.

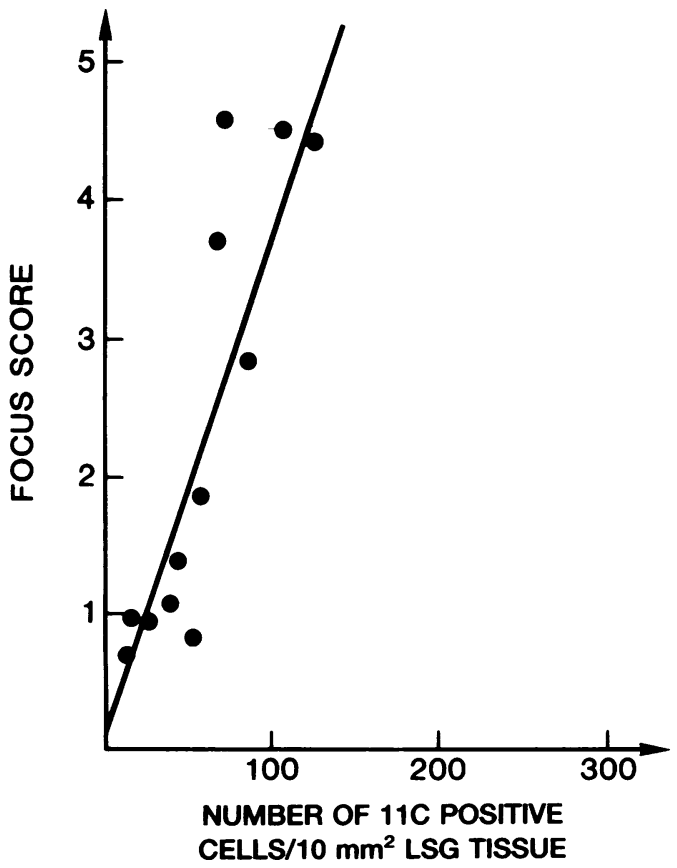

Figure 6 Dependence of histamine containing $11 C$ positive cells on the intensity of the local tissue inflammation as assessed by focus score counting. $y=-0.033+0.037 x$, $r=0.837, p<0.001$ in linear regression analysis. $L S G=$ labial salivary gland. 
inflammation and the number of mast cells containing histamine $(y=-0.033+0.037 x$, $r=0.837, p<0.001$; fig 6$)$. There was no clearcut difference between primary and secondary Sjögren's syndrome as to mast cell numbers in toluidine blue and 11C staining. Because only two patients in this series had primary Sjögren's syndrome, however, the possibility of a difference remains.

The ultrastructural appearance of the mast cells was normal. The mast cells were characteristic, with membrane bound secretory granules lacking signs of degranulation filling up a large part of the cytoplasm. The nuclei were round or ovoid, and the plasma membrane contained several microvilli (fig 3). No degranulated mast cells were seen in situ in the labial salivary gland biopsy specimens studied.

\section{Discussion}

In this study the presence of mast cells in labial salivary gland biopsy specimens was shown by histochemical toluidine blue staining, immunohistochemical histamine staining, and transmission electron microscopic evaluation of the fine structure. Toluidine blue staining shows the proteoglycan matrix of the mast cell granules, the heterologous $11 \mathrm{C}$ antiserum labels mast cell mediator histamine, and transmission electron microscopy demonstrates the typical ultramorphology..$^{15}$ Although mast cells show heterogeneity in their histochemical, functional and morphological criteria, ${ }^{17}$ our study, based on three different, independent methods, established beyond any doubt that mast cells are present in diseased salivary glands in Sjögren's syndrome.

Mast cells have been implicated in various diseases, particularly allergic rhinitis, asthma, and anaphylaxis. Mast cells modify homeostatic regulation and effect functions, such as mucus production, microcirculation and blood vessel growth, and bone remodelling. They have also been implicated as markers of inflammatory disorders. ${ }^{618}$ In particular, mucosal type mast cells-easily overlooked in routine histological analysis owing to poor visualisation after formalin fixation-depend on $T$ cell derived interleukin-3 for their proliferation. ${ }^{17-19}$ The factors regulating the proliferation of connective tissue mast cells are less clear but they seem to be derived from macrophages and fibroblasts. ${ }^{20}$ Therefore, one would expect that active focal sialadenitis would be accompanied by extensive proliferation of mast cells in situ. The extent of labial salivary gland participation can be assessed by focus score counting according to Greenspan. ${ }^{814}$ Comparison of the focus score and the number of mast cells assessed by routine toluidine blue staining with the aid of linear regression analysis showed no clear-cut positive correlation. This finding suggests that there are factors other than local $T$ cell activation and interleukin-3 production that affect the number of cells metachromatically staining positive with toluidine blue.

The number of metachromatic cells stained by toluidine blue was consistently higher than the number of cells containing histamine stained by the $11 \mathrm{C}$ antiserum. ${ }^{12} 13$ This suggests that labial salivary gland mast cells are a heterogeneous population. ${ }^{21} 22$ Interestingly, there was a highly significant positive correlation between the number of histamine stainable mast cells and the degree of the local immune inflammation as assessed by focus score counting. This suggests that the number of histamine stainable mast cells-in contrast with cells staining positive with toluidine blue-may be used as a marker of local inflammation. Connective tissue mast cells contain much more histamine than mucosal mast cells $(10-30 \mathrm{pg} / \mathrm{cell} v$ $<0.2 \mathrm{pg} /$ cell $\left.^{17}\right)$. Possibly, therefore, it may be the number of histamine rich connective tissue mast cells and not the number of mucosal mast cells that is regulated by the intensity of focal sialadenitis in labial salivary glands in patients with Sjögren's syndrome. This is compatible with the earlier findings suggesting that, apart from the major histocompatibility complex locus II Ia antigen expression in small lymphocytes, signs of $T$ cell blast transformation are scanty in situ in labial salivary gland biopsy specimens in Sjögren's syndrome. ${ }^{23}$ Possibly, there is a local macrophage activation in labial salivary glands in Sjögren's syndrome, but this has not been studied.

We also considered the possibility that degranulation and depletion of the granular histamine content may explain the discrepancy between the number of cells staining positive with toluidine blue and the number of mast cells containing histamine. Transmission electron microscopy did not disclose ultramorphological signs of degranulation, however. It therefore seems that mast cells-although useful as markers of inflammation-may not be actively influencing the local disease process. On the other hand, it seems that by using toluidine blue staining of the granule proteoglycan matrix, we can avoid the 'false negative' results seen when histamine staining is used in the assessment of labial salivary gland mast cells.

Interactions between antigen presenting cell or antigen, or both, with $\mathrm{T}$ and $\mathrm{B}$ lymphocytes have been usually regarded as central in the pathogenesis of Sjögren's syndrome. ${ }^{6}$ Recent evidence suggests that the salivary duct epithelial cells might be the primary target for a viral infection, ${ }^{24}{ }^{25}$ for example, though it is difficult to exclude the possibility that the immunological disturbances only allow abnormal expression of incorporated or episomal viral genome in cells so affected. ${ }^{26}$ In any case it is unlikely that lymphocyte activation itself would be enough to cause destruction of salivary glands. One of the possible non-specific effector mechanisms recruited is the mast cell system. ${ }^{18-20}$ Our study clearly shows that the mast cells are affected and serve a useful purpose as markers of inflammation. In spite of this there was no ultramorphological evidence for en masse degranulation of the local mast cells. This does not exclude the possible release of various potent mast cell mediators, which include bioactive amines, eicosanoids, and various polypeptide mediators. ${ }^{22}$ Therefore, further studies are needed to assess more specifically an eventual pathogenetic role in Sjögren's syndrome of these intriguing cells. 
Supported by the Sigrid Juselius Foundation, the Linda Gadd Foundation and the Academy of Finland. Dr Orhan Guven, of Ankara, Turkey, was supported by a grant from the Turkish Ministry of Education.

1 Kaliner $\mathbf{M}$, Lemanske $\mathbf{R}$. Inflammatory responses to mast cell granules. Fed Proc 1984; 43: 2846-51.

2 Bienenstock J, Tomioka M, Stead R, et al. Mast cell involvement in various inflammatory processes. Am Rev Respir Dis 1987; 135: S5-8.

3 Gruber B, Poznansky M, Boss E, Partin J, Gorevic P, Kaplan A P. Characterization and functional studies of rheumatoid synovial mast cells. Activation by secretagogues, anti-IgE, synovial mast cells. Activation by secretagogues, anti-IgE,
and histamine-releasing lymphokine. Arthritis Rheum 1986; and histamine

4 Malone D G, Wilder R L, Saavedra-Delgado A M, Metcalfe $D$ D. Mast cell numbers in rheumatoid synovial tissues. Correlations with quantitative measures of lymphocytic infiltration and modulation by antiinflammatory therapy. Arthritis Rheum 1987; 30: 130-7.

5 Talal N. Recent developments in the immunology of Siögren's syndrome (autoimmune exocrinopathy). Scand $\mathcal{F}$ Rheumatol [Suppl] 1986; 61: 76-82.

6 Konttinen Y T, Malmström M. Immunopathologic and histologic findings in Sjögren's syndrome. Sjögren's syndrome: a model for autoimmunity and malignancy. In: Andrianakos A, Kappou I, Mavrikakis M, Moutsopoulos H H, eds. Eurorheumatology. Proceedings from plenary lectures and round table discussions of the XIth European congress of rheumatology. Athens, Greece: Tagas, 1987: 162-5.

7 Syrjänen S, Syrjänen K. Mast cells in the labial salivary glands of patients suffering from rheumatoid arthritis. Scand 7 Dent Res 1984; 92: 557-63.

8 Daniels T E. Labial salivary gland biopsy in Siögren's syndrome. Assessment as a diagnostic criterion in 362 syndrome. Assessment as a diagnostic criterion

9 Manthorpe R, Oxholm P, Prause J U, Schiodt M. The Copenhagen criteria for Sjögren's syndrome. Scand $\mathcal{f}$ Rhewmatol [S uppl] 1986; 61: 19-21.

10 Arnett F C, Edworthy S M, Bloch D A, et al. The American Rheumatism Association 1987 revised criteria for the classification of theumatoid arthritis. Arthritis Rheum 1988; 31: 315-24.

11 Sternberger L A, Hardy P H, Cuculis J J, Meyer H G. The unlabeled antibody enzyme method for immunohistochemistry. Preparation and properties of soluble antigenantibody complex (horseradish peroxidase-antihorseradish peroxidase) and its use in identification of spirochetes. $\mathcal{f}$ Pistochem Cytochem 1970; 18: 315-33.

12 Panula P, Yang H-Y T, Costa E. Histamine-containing neurons in the rat hypothalamus. Proc Natl Acad Sci USA 1984; 81: 2572-8.

13 Panula P. Histamine in the nervous system. In: Panula $P$, Päivärinta $\mathrm{H}$, Soinila $\mathrm{S}$, eds. Neurohistachemistry: moderm methods and applications. Vol 16. Neurology and neurobiology. New York: Alan R Liss, 1986: 425-42.

14 Greenspan J S, Daniels T E, Talal N, Sylvester R A. The histopathology of Siögren's syndrome in labial salivary gland biopsies. Oral Surg Oral Med Oral Pathol 1974; 37:
217-29.

15 Gall S J, Dvorak H F. Basophils and mast cells; morphologic insights into their biology, secretory patterns and function. Prog Allergy 1984; 34: 1-141.

16 Holgate S T, Kay A B. Mast cells, mediators and asthma Clin Allergy 1985; 15: 221-34.

17 Siraganian R P. Mast cells and basophils. In: Gallin J I, Goldstein I M, Snyderman R, eds. Inflammation: basic principles and clinical correlates. New York: Raven Press, 1988: $513-43$.

18 Wasserman S I. The mast cell and synovial inflammation. Or, what's a nice cell like you doing in a joint like this? Arthritis Rheum 1984; 27: 841-4.

19 Tuominen S, Malmström M, Hietanen J, Konttinen Y T. A review of mast cells and their mediators. Proc Finn Dent Soc 1989; 85: 125-37.

20 Metcalfe D D. Effector cell heterogeneity in immediate hypersensitivity reactions. Clin Rev Allergy 1983; 1: 311-25.

21 Metcalfe D D, Kaliner M, Donlon M A. The mast cell. CRC Crit Rev Immunol 1981; 3: 23-74.

22 Schwartz L B. Mediators of human mast cells and human mast cell subsets. Ann Allergy 1987; 58: 226-35.

23 Segerberg-Konttinen $M$, Bergroth $V$, Jungell $P$, et al. lymphocyte activation state in the minor salivary glands of patients with Siögren's syndrome. Ann Rheum Dis 1987; 46: $649-53$.

24 Green J E, Hinrichs S H, Vogel J, Jay G. Exocrinopathy resembling Sjögren's syndrome in HTLV-1 tax transgenic mice. Nature $1989 ; 341: 72-4$.

25 Keinänen R, Konttinen Y T, Segerberg-Konttinen M, et al. Contemplation of virally induced changes in salivary glands in Sjögren's syndrome: on the use of in situ hybridization in such studies. Foumal of Autoimmunity 1989; 2: 569-78.

26 Konttinen Y T, Bluestein H G, Zvaifler N J A defective control of EBV transformed, immortalized B cells by cytotoxic T cells in rheumatoid arthritis. In: Machtey I, ed. Progress in rheumatology. Vol 3. Petah-Tiqva Israel: Rheumatology Service, Golda Medical Center, 1987: 4-8. 